\title{
Pelaksanaan Skrining Prakonsepsi pada Calon Pengantin Perempuan
}

\author{
Eka Vicky Yulivantina ${ }^{1}$, Mufdlilah ${ }^{2}$, Herlin Fitriana Kurniawati ${ }^{3}$ \\ ${ }^{1}$ Program Studi Kebidanan, Program Sarjana Stikes Guna Bangsa, Yogyakarta, Indonesia \\ ${ }^{2.3}$ Program Studi IImu Kebidanan, Program Magister Kebidanan, Universitas Asiyiyah, Yogyakarta, Indonesia \\ Korespondensi: ekavicky.yulivantina@gunabangsa.ac.id
}

Submisi: 17 April 2020; Revisi:13 Maret 2021; Penerimaan: 18 Maret 2021

\begin{abstract}
Background: Preconception health is a part of whole health both in males and females during reproductive period. Preconception screening is useful for decreasing risks and promote healthy life style in order to prepare a healthy pregnancy.

Objective: To explore preconception screening on brides to be.

Method: The study employed qualitative method with phenomenology approach.

Results adn Discussion: The implementation of preconception screening for brides to be consists of a physical examination, supporting examinations in the form of mandatory laboratory examinations and recommendations, Tetanus Toxoid immunization, nutritional supplementation, health consultations and psychological services.

Conclusion: Preconception screening implementation has fulfilled minimum standard.
\end{abstract}

Keywords: Brides to be; preconception screening

\section{ABSTRAK}

Latar Belakang: Kesehatan prakonsepsi merupakan bagian dari kesehatan secara keseluruhan antara perempuan dan laki-laki selama masa reproduksinya. Skrining prakonsepsi berguna untuk mengurangi resiko dan mempromosikan gaya hidup sehat untuk mempersiapkan kehamilan sehat. Tujuan: Untuk mengeksplorasi pelaksanaan skrining prakonsepsi pada calon pengantin perempuan.

Metode: Penelitian kualitatif dengan pendekatan fenomenologi.

Hasil dan Pembahasan: Pelaksanaan skrining prakonsepsi pada calon pengantin perempuan terdiri dari pemeriksaan fisik, pemeriksaan penunjang berupa pemeriksaan laboratorium wajib dan rekomendasi, pemberian imunisasi Tetanus Toxoid, suplementasi gizi, konsultasi kesehatan dan pelayanan psikologi.

Kesimpulan: Pelaksanaan skrining prakonsepsi sudah mengacu pada standar minimal.

Kata Kunci: Calon pengantin perempuan; skrining prakonsepsi 


\section{PENDAHULUAN}

Kesehatan reproduksi menjadi titik awal perkembangan kesehatan ibu dan anak yang dapat dipersiapkan sejak dini, bahkan sebelum seorang perempuan hamil dan menjadi ibu. Kesehatan prakonsepsi merupakan bagian dari kesehatan secara keseluruhan antara perempuan dan laki-laki selama masa reproduksinya. Perawatan kesehatan prakonsepsi berguna untuk mengurangi resiko dan mempromosikan gaya hidup sehat untuk mempersiapkan kehamilan sehat. ${ }^{1}$

Perawatan kesehatan prakonsepsi merupakan perawatan yang mengacu pada intervensi biomedis, perilaku, dan pencegahan sosial yang dapat meningkatkan kemungkinan memiliki bayi yang sehat. Untuk dapat menciptakan kesehatan prakonsepsi dapat dilakukan melalui skrining prakonsepsi. Skrining prakonsepsi sangat berguna dan memiliki efek positif terhadap kesehatan ibu dan anak. Penerapan kegiatan promotif, intervensi kesehatan preventif dan kuratif sangat efektif dalam meningkatkan kesehatan ibu dan anak sehingga membawa manfaat kesehatan untuk remaja, baik perempuan dan laki-laki selama masa reproduksinya baik sehat secara fisik, psikologis dan sosial, terlepas dari rencana mereka untuk menjadi orang tua. ${ }^{1}$

Manfaat dari skrining prakonsepsi adalah menurunkan angka kematian ibu dan bayi, mencegah kehamilan tidak diinginkan, mencegah komplikasi dalam kehamilan dan persalinan, mencegah kelahiran mati, prematur dan bayi dengan berat lahir rendah, mencegah terjadinya kelahiran cacat, mencegah infeksi pada neonatal, mencegah kejadian underweight dan stunting sebagai akibat dari masalah nutrisi ibu, mengurangi resiko diabetes dan penyakit kardiovaskuler dalam kehamilan dan mencegah penularan Human Immunodeficience Virus dari ibu kejanin. ${ }^{1}$

Berdasarkan hasil studi pendahuluan pada bulan Maret 2018, Kota Yogyakarta merupakan satu-satunya yang menyelenggarakan pelayanan skrining prakonsepsi melalui pemeriksaan fisik dan psikologis di seluruh puskesmasnya. Berdasarkan hasil studi pendahuluan pada Dinas Kesehatan Kota Yogyakarta, didapatkan informasi bahwa Puskesmas
Tegalrejo, Puskesmas Keraton dan Puskesmas Gondokusuman 1 merupakan 3 Puskesmas dengan cakupan imunisasi tetanus toxoid pada calon pengantin yang tertinggi di Kota Yogyakarta.

Peneliti melakukan pengkajian pada setiap puskesmas dan didapatkan informasi bahwa Puskesmas Tegalrejo merupakan puskesmas dengan jumlah wanita usia subur tertinggi dari 18 puskesmas di Kota Yogyakarta yaitu sebanyak 7135 wanita usia subur $(9,02 \%)$. Pelayanan skrining prakonsepsi di Puskesmas Tegalrejo terdiri dari pemeriksaan fisik, pemeriksaan psikologis, pemberian konseling gizi dan pemberian imunisasi Tetanus Toxoid. Untuk pelaksanaan skrining prakonsepsi di Puskesmas Tegalrejo pada bulan Januari sampai Maret 2018 dari total calon pengantin sejumlah 59 orang, hanya $86,44 \%$ calon pengantin yang mendapatkan pelayanan prakonsepsi lengkap di Puskesmas Tegalrejo. Peneliti kemudian melakukan studi pendahuluan kepada 5 calon pengantin yang melakukan skrining prakonsepsi, 2 calon pengantin mengatakan tidak mendapatkan pemeriksaan psikologis, 2 calon pengantin mengatakan tidak akan menunda kehamilan walaupun mereka mengalami anemia, 1 calon pengantin mengatakan direkomendasikan untuk hamil di usia 20 tahun tetapi tidak paham bagaimana caranya agar tidak terjadi kehamilan. Penelitian ini bertujuan untuk mengeksplorasi pelaksanaan skrining prakonsepsi pada calon pengantin perempuan di Puskesmas Tegalrejo Kota Yogyakarta.

\section{METODE}

Penelitian ini dilaksanakan di Puskesmas Tegalrejo Kota Yogyakarta menggunakan metode kualitatif dengan pendekatan fenomenologi. Jumlah partisipan dalam penelitian ini sejumlah 19 partisipan yang terdiri dari 15 partisipan utama dan 4 partisipan pendukung. Teknik pengambilan sampel dalam penelitian ini menggunakan tekhnik purposive sampling yaitu pengambilan responden didasarkan pada tujuan dan kriteria tertentu yang telah ditetapkan. Pengambilan responden dalam penelitian ini didasarkan pada tujuan penelitian yaitu untuk mengeksplorasi pelaksanaan skrining prakonsepsi pada calon pengantin perempuan. 


\section{HASIL DAN PEMBAHASAN}

Pelaksanaan skrining prakonsepsi pada calon pengantin perempuan di Puskesmas Tegalrejo dilaksanakan secara terpadu. Adapun poli yang terlibat dalam pelaksanaan skrining prakonsepsi adalah poli Kesehatan Ibu dan Anak, laboratorium, poli gizi, poli umum dan poli psikolog. Hal ini didukung dengan hasil wawancara sebagai berikut:

"Jadi kalau caten itu kan daftarnya nanti ke KIA, nah ini kan terpadu melibatkan beberapa poli mbak. Setelah dari KIA kan dirujuk ke lab. Nah dari hasil lab tersebutlah nanti terus ke gizi. Karena kalau hasil lab yang $\mathrm{Hb}$ dan PP test belum keluar, maka kami belum bisa memberikan konseling. Begitu juga poli psikolog. Karena kan percuma, ya nanti kalau hasilnya baik, kalau hasilnya jelek? nah nanti bahan yang diberikan untuk konsultasi kan kurang tepat kalau hasil lab belum keluar" (UG 1)

\section{Pemeriksaan Fisik}

Pemeriksaan fisik pada calon pengantin perempuan di Puskesmas Tegalrejo terdiri dari penimbangan berat badan, pemeriksaan tekanan darah dan pemeriksaan lingkar lengan atas. Hal ini diperjelas dengan bukti wawancara sebagai berikut :

"Yang pertama daftar, terus dapat status, dibawa ke KIA, di KIA di ukur fisiknya seperti timbang berat badan dan ukur lila, vital sign, kemudian dapat surat pengantar ke laboratorium..." (UB1)

Berdasarkan hasil wawancara di atas, pemeriksaan fisik dilaksanakan di poli Kesehatan Ibu dan Anak, petugas pelaksana di poli Kesehatan Ibu dan Anak adalah bidan. Calon pengantin setelah mendaftar akan diarahkan ke poli Kesehatan Ibu dan Anak, di poli Kesehatan Ibu dan Anak calon pengantin perempuan akan di anamnesa untuk di gali informasi mengenai hari pertama haid terakhir, rencana menikah dan keluhan yang dirasakan. Pada pemeriksaan fisik di lakukan pengukuran berat badan, pengukuran tekanan darah dan pengukuran lingkar lengan atas.

\section{Pemeriksaan Penunjang}

Pemeriksaan penunjang pada calon pengantin perempuan di Puskesmas Tegalrejo dilakukan di unit laboratorium. Adapun pemeriksaan yang wajib dilaksanakan dalam paket layanan terpadu adalah pemeriksaan kehamilan (urine) dan pemeriksaan kadar hemoglobin dan pemeriksaan penunjang yang bersifat rekomendasi. Hal ini diperjelas dengan bukti wawancara sebagai berikut :

"...Sama lab, labnya ada $\mathrm{Hb}$, ada test urine untuk test kehamilan, itu yang wajib. Kalau untuk yang penunjangnya bisa kita tawarkan untuk gula darah sama kolesterol, nanti untuk persiapan kehamilannya juga. Catinnya boleh memilih untuk yang penunjang, misalnya ada riwayat gula darah dalam keluarga maka dianjurkan untuk melakukan pemeriksaan. Tujuannya seperti itu"(UB2)

"lya ada pemeriksaan yang bersifat rekomendasi, sebenarnya kan kita skrining penyakit tidak menular itu kan sejak usia ya 20 ya, sehingga ditawarkan ke caten jadi untuk skrining kayak kolesterol, gula, terus emm kalau yang untuk penyakit menularnya terutama untuk yang status HIV nya kayak gitu cuman itu belum wajib. Hepatitis $B$ ada cuman bagi yang mau sih, belum jadi program wajib"(UD 1)

\section{Pemberian Imunisasi}

Pemberian imunisasi merupakan bagian terpenting dalam layanan skrining prakonsepsi pada calon pengantin perempuan. Imunisasi yang diberikan kepada calon pengantin perempuan adalah imunisasi Tetanus Toxoid. Bukti imunisasi Tetanus Toxoid harus diserahkan ke Kantor Urusan Agama sebagai salah satu syarat administrasi mendaftar pernikahan. Hal ini didukung dengan hasil wawancara sebagai berikut :

"...Yang mendukung ini dari KUA. Karena ada syarat TT untuk menikah..." (UB 1) 


\section{Suplementasi Gizi}

Suplementasi gizi pada calon pengantin di puskesmas Tegalrejo diberikan berdasarkan keadaan calon pengantin perempuan itu sendiri. Bila calon pengantin perempuan memenuhi syarat untuk hamil dan tidak menunda kehamilan maka akan diberikan suplementasi asam folat. Hal ini didukung dengan hasil wawancara sebagai berikut :

"Oh ya mbak catinnya juga dapat asam folat mbak, untuk persiapan kehamilannya. Setiap catin yang memang memenuhi syarat untuk hamil dikasih asam folat. Kalau yang menunda atau misal belum cukup umur emm ga dikasih ya..." (UB 1)

Hal serupa juga disampaikan oleh calon pengantin yang tidak menunda kehamilan berikut ini :

"...Terus juga yang dikasih obat asam folat itu untuk persiapan kehamilan...." (UC 8)

\section{Konsultasi Kesehatan}

Konsultasi kesehatan pada pelaksanaan skrining prakonsepsi di Puskesmas Tegalrejo dilakukan hampir di setiap poli. Poli Kesehatan Ibu dan Anak, poli gizi, poli umum dan poli psikologi memberikan konseling berdasarkan hasil laboratorium dan keluhan dari calon pengantin. Hal ini didukung dengan hasil wawancara sebagai berikut :

"kemudian konseling juga kalau memang butuh konseling. Menyesuaikan hasil labnya.." (UD 1)

\section{Pelayanan Psikologi}

Pelayanan psikologi pada calon pengantin merupakan bagian dari layanan terpadu pada calon pengantin di Puskesmas Tegalrejo. Hal ini tercantum dalam standar operasional prosedur pelayanan calon pengantin No SOP/TR/KIA/04/2016 pada prosedur ke 8 bahwa petugas memberikan rujukan internal kepada pasien untuk mendapatkan konsultasi ke ruang konsultasi gizi dan konsultasi psikologi. Hal ini didukung pula dengan hasil wawancara sebagai berikut :

"...Untuk dikota kan layanan psikolog itu adalah layanan tambahan yang wajib ya mbak..."(IP 2)
Pelaksanaan skrining prakonsepsi di Indonesia di atur dalam Peraturan Menteri Kesehatan No 97 Tahun 2014 Tentang pelayanan kesehatan masa sebelum hamil, masa hamil, persalinan, dan masa sesudah melahirkan, penyelenggaraan pelayanan kontrasepsi, serta pelayanan kesehatan seksual. Pelayanan kesehatan masa sebelum hamil dilakukan untuk mempersiapkan perempuan dalam menjalani kehamilan dan persalinan yang sehat dan selamat serta memperoleh bayi yang sehat. ${ }^{2}$

Sasaran pelayanan kesehatan masa sebelum hamil berdasarkan Permenkes No.97 Tahun 2014 adalah remaja, calon pengantin dan pasangan usia subur. Berdasarkan hasil pengkajian di Puskesmas Tegalrejo, pelayanan skrining prakonsepsi di Puskesmas Tegalrejo terutama di tekankan kepada calon pengantin untuk mempersiapkan kesehatan calon pengantin secara fisik dan mental dalam menghadapi kehamilan sebagai upaya menyiapkan ibu hamil sehat, menurunkan angka kematian ibu dan bayi. Hal ini sejalan dengan hasil penelitian dari Dean, et al (2014) bahwa fungsi dari skrining prakonsepsi adalah untuk mengetahui status kesehatan fisik dan emosional ibu dan pasangan sehingga dapat menjadi dasar dalam pemberian intervensi untuk menyiapkan kehamilan yang optimal. Mayoritas pasangan yang memang merencanakan kehamilan dapat merasakan manfaat skrining prakonsepsi, baik bagi mereka yang hanya ingin memberikan yang terbaik bagi bayinya maupun sebagai upaya mengurangi kondisi yang dapat membahayakan kehamilan. $^{3}$

Pada pelaksanaan skrining prakonsepsi di Puskesmas Tegalrejo, kegiatan pemeriksaan fisik pada calon pengantin sudah sesuai dengan Permenkes No.97 Tahun 2014 bahwa pemeriksaan fisik yang dimaksudkan dalam pelayanan masa sebelum hamil paling sedikit meliputi pemeriksaan tanda vital dan pemeriksaan status gizi. Pemeriksaan status gizi harus dilakukan terutama untuk menanggulangi masalah kurang energi kronis dan pemeriksaan status anemia.

Pemeriksaan fisik pada calon pengantin di Puskesmas Tegalrejo meliputi pemeriksaan tandatanda vital, penimbangan berat badan dan pengukuran lingkar lengan atas untuk mengetahui status gizi calon pegantin. Pemeriksaan berat badan dan pengukuran 
status gizi sangat diperlukan karena berat badan dan status gizi mempengaruhi kehamilan bila tidak disiapkan dari masa prakonsepi. Hal ini sejalan dengan hasil penelitian dari Dean, et al (2014) bahwa berat badan ibu hamil sebelum hamil adalah faktor signifikan yang berkontribusi terhadap komplikasi dalam kehamilan dan persalinan. Perempuan yang underweight pada periode prakonsepsi berkontribusi $32 \%$ lebih tinggi terhadap risiko kelahiran prematur $32 \%$, perempuan dengan obesitas beresiko dua kali lipat mengalami preeklampsia dan diabetes gestasional. Perempuan dengan obesitas dan obesitas lebih dari dua kali lipat risiko preeklamsia. ${ }^{3}$

Status gizi pada calon pengantin di Puskesmas Tegalrejo diperiksa agar dapat dilakukan rencana tindak lanjut asuhan pada calon pengantin yang memiliki masalah gizi. Hal ini sejalan dengan hasil penelitian dari Prendergast dan Humphrey (2014) bahwa status gizi dan kesehatan ibu sebelum, selama dan setelah kehamilan mempengaruhi pertumbuhan awal anak dan perkembangannya sejak dalam kandungan. Kehamilan dengan kekurangan energi kronis menyebabkan kejadian stunting pada anakanak sebesar $20 \%$. Penyebab lain dari sisi ibu antara lain ibu yang memiliki perawakan pendek, jarak kelahiran yang terlalu dekat dan kehamilan remaja. ${ }^{4}$

Pemeriksaan penunjang wajibyang dilaksanakan di Puskesmas Tegalrejo adalah pemeriksaan urine dan pemeriksaan kadar hemoglobin. Pemeriksaan lain yang direkomendasikan oleh puskesmas Tegalrejo adalah pemeriksaan gigi, pemeriksaan kadar gula darah, kolesterol, asam urat serta pemeriksaan penyakit menular seperti hepatitis B dan infeksi menular seksual. Pengukuran kadar hemoglobin sebagai pemeriksaan penunjang wajib di Puskesmas Tegalrejo sangat penting untuk dilakukan karena kebanyakan perempuan tidak merencanakan kehamilan dengan baik sehingga bila dari masa prakonsepsi ibu sudah mengalami sub optimal nutrisi maka mereka risiko lebih tinggi untuk mengalami anemia defisiensi besi pada kehamilan. Hal ini sejalan dngan penelitian dari Dainty, et al (2014) bahwa pentingnya skrining status anemia pada masa prakonsepsi adalah agar dapat diketahui kadar hemoglobin pada calon pengantin sehingga bila terjadi anemia defisiensi besi dapat dilakukan upaya pengobatan sebelum terjadi kehamilan. ${ }^{5}$
Pemeriksaan penunjang yang dianjurkan di puskesmas Tegalrejo diantaranya adalah pemeriksaan kadar gula darah. Hal yang mendasari dianjurkannya pemeriksaan kadar gula darah pada calon pengantin di Puskesmas Tegalrejo adalah banyak ditemukannya pasangan usia subur terutama perempuan yang menderita diabetes mellitus. Pemeriksaan ini penting dilakukan bagi calon pengantin perempuan beresiko untuk mengetahui kadar gula darah pada calon pengantin sehingga bisa meminimalisir resiko komplikasi pada kehamilan. hal ini sejalan dengan hasil penelitian dari Wahabi, et al (2010) bahwa skrining diabetes mellitus pada masa prakonsepsi bermanfaat terhadap pengelolaan gula darah yang lebih baik sebelum terjadi kehamilan, pemberian suplementasi asam folat tiga bulan sebelum konsepsi, kondisi metabolik yang lebih baik selama kehamilan, menurunnya risiko aborsi dan menurunnya angka kematian bayi sehingga secara tidak langsung mengurangi komplikasi pada kehamilan. ${ }^{6}$

Selain pemeriksaan kadar gula darah, pemeriksaan penunjang yang direkomendasikan kepada calon pengantin di Puskesmas Tegalrejo adalah pemeriksaan HIV/AIDS. Pemeriksaan status HIV pada calon pengantin di Puskesmas Tegalrejo bertujuan untuk menurunkan angka penularan HIV/AIDS kepada pasangan maupun kepada janin yang dikandung oleh ibunya kelak. Hal ini sejalan dengan hasil penelitian dari Manakan dan Sutan (2017) bahwa skrining HIV pada pasangan sebelum menikah terbukti mengurangi penularan HIV/AIDS. ${ }^{7}$

Pemberian imunisasi tetanus toxoid pada calon pengantin perempuan di Puskesmas Tegalrejo dilakukan dalam upaya pencegahan dan perlindungan terhadap penyakit tetanus. Pemberian imunisasi tetanus toxoid dilakukan untuk mencapai status imunisasi tetanus toxoid ke 5 hasil pemberian imunisasi dasar dan lanjutan. Status imunisasi tetanus toxoid ke 5 (lengkap) ditujukan agar wanita usia subur memiliki kekebalan penuh terhadap infeksi tetanus toxoid. Hal ini sejalan dengan hasil penelitian dari Lassi, et al (2014) bahwa imunisasi selama periode prakonsepsi dapat mencegah banyak penyakit yang mungkin memiliki konsekuensi serius atau bahkan terbukti fatal bagi ibu atau bayi yang baru lahir. ${ }^{8}$ 
Standar nasional pelayanan skrining prakonsepsi lainnya adalah suplementasi gizi pada calon pengantin. Pemberian suplementasi gizidi Puskesmas Tegalrejo berupa asam folat bagi calon pengantin yang tidak menunda kehamilan dan calon pengantin yang mengalami anemia. Hal ini sejalan dengan hasil penelitian dari Opon, et al (2017) bahwa ibu hamil biasanya tidak menyadari bahwa dirinya hamil pada awal kehamilan. sehingga suplementasi asam folat lebih baik diberikan dari sebelum hamil. Suplai asam folat yang tepat dari masa prakonsepsi, kehamilan dan laktasi sangat menentukan perkembangan dan pertumbuhan janin yang tepat. Asam folat adalah zat yang paling penting dalam unsur-unsur sel-sel pembagi karena memainkan peran penting dalam sintesis deoxyribonucleic acid (DNA). Pada awal kehamilan, permintaan asam folat yang tidak disintesis dalam tubuh manusia meningkat. Asam folat yang dapat dipenuhi melalu pasokan makanan yang kaya asam folat hanya sekitar 150-250 $\mu$ g. ${ }^{9}$

Hal ini sejalan pula dengan penelitian dari Wen, et al (2016) bahwa kekurangan asam folat meningkatkan risiko terjadinya kecacatan saraf tabung (neuro tube defect), bibir sumbing dan down syndrome. Gangguan metabolisme folat dapat menyebabkan hyperhomocysteinaemia dan komplikasi yang lebih sering terjadi pada kehamilan, seperti keguguran berulang, pertumbuhan janin terhambat dan pre eklampsia. ${ }^{10}$

Pemeriksaan lain yang wajib diakses oleh calon pengantin perempuan di Puskesmas Tegalrejo adalah pemeriksaan psikologi. Pemeriksaan psikologi memiliki peran penting dalam mempersiapkan mental calon pengantin menghadapi pernikahan, kehamilan, persalinan, nifas dan keluarga berencana. Hal ini sejalan dengan hasil penelitian dari Lassi, et al (2014) bahwa masalah kesehatan mental ibu sering tidak terdiagnosis dan tidak mendapatkan perawatan kesehatan. hasil penelitian menunjukkan keterkaitan antara kesehatan mental remaja yang buruk dan kehamilan yang buruk terhadap kesehatan janin. Perawatan prakonsepsi untuk kondisi kejiwaan seharusnya selalu dilakukan pada wanita usia subur. Untuk mengidentifikasi adanya gangguan jiwa. Sehingga dapat diberikan penanganan lebih lanjut sebelum terjadi kehamilan. misalnya konseling pada perempuan dengan gangguan depresi dan kecemasan dan pendampingan agar depresi dan kecemasan tidak berlanjut hingga pada kehamilan dan berdampak pada ibu dan janin seperti ingin mengakhiri kehamilan, bunuh diri dan lain-lain (Lassi, et al 2014).

\section{KESIMPULAN DAN SARAN}

Pelaksanaan skrining prakonsepsi di Kota Yogyakarta sudah memenuhi standar minimal. Diperlukan optimalisasi pelayanan untuk memaksimalkan pelayanan skrining prakonsepsi pada calon pengantin perempuan di Kota Yogyakarta.

\section{DAFTAR PUSTAKA}

1. World Health Organization. 2013. Preconception care: Maximizing the gains for maternal and child health. http://www.who.int/maternal_ child_adolescent/documents/concensus_ preconception_care/en/

2. Permenkes. 2014. Peraturan Menteri Kesehatan No 97 Tahun 2014 Tentang Pelayanan Kesehatan Masa Sebelum Hamil, Masa Hamil, Persalinan, Dan Masa Sesudah Melahirkan, Penyelenggaraan Pelayanan Kontrasepsi, Serta Pelayanan Kesehatan Seksual. http://kesga.kemkes.go.id/ images/pedoman/PMK\%20No.\%2097 \%20 ttg\%20Pelayanan\%20Kesehatan\%20Kehamilan. pdf.

3. Dean, et al. 2014. Preconception care: nutritional risks and interventions. http://www.reproductivehealth-journal.com/content/11/S3/S3.

4. Prendergast, Andrew J dan Humphrey Jean H. 2014. The stunting syndrome in developing countries. https://www.ncbi.nlm.nih.gov/pmc/ articles/PMC4232245/

5. Dainty JR,et al. 2014. Estimation of Dietary Iron Bioavailability From Food Iron Intake and Iron Status. PLoS One 2014; 9: e111824.

6. Wahabi HA,et al. 2010. Preconception care for diabetic women for improving maternal and fetal outcomes: a systematic review and metaanalysis. http://wrap.warwick.ac.uk/63107/1/ WRAP_Preconception $\% 20$ care $\% 20$ for $\% 20$ diabetic\%20women.pdf. 
7. Manakandan, Sujith Kumar dan Sutan Rosan. 2017. Expanding the Role of Pre-Marital HIV Screening: Way Forward for Zero New Infection. Open Journal of Obstetrics and Gynecology, 7, 71-79.

8. Lassi, et al. 2014. Preconception care: delivery strategies and packages for care. http://www. reproductive-health-journal.com/content/11/ s3/S7.
9. Opon,et al. 2017. Folate supplementation during the preconception period, pregnancy and puerperium. Ginekologia Polska 2017, vol. 88 , no. 11.

10. Wen,et al. 2016. Folic Acid Supplementation in Pregnancy and the Risk of Pre- Eclampsia-A Cohort Study. PLoS One. 2016; 11(2): e0149818, doi: 10.1371/journal.pone.0149818, indexed in Pubmed: 26901463. 